Yasminar Amaerita Telaumbanua $^{1}$

\title{
AN ANALYSIS OF STUDENTS' SKRIPSI ERRORS IN USING ARTICLES AT ENGLISH EDUCATION STUDY PROGRAM OF IKIP GUNUNGSITOLI YEAR 2018/2019
}

\begin{abstract}
Writing skripsi is an obligatory scientific work for students at the last semester at English education study program of IKIP Gunungsitoli. It is done through a research. The research is conducted based on a certain research design. Teacher-researcher did a research to describe what article errors done by the students, how many times the students are writing article errors and why the students cannot revise the article errors successfully particularly in Chapter I. The data source was from the three skripsi done by three students who graduated faster, 3 years and half. As the research findings, the teacher-researcher found there were three kinds of article errors done by the three students in their skripsi in Chapter I namely indefinite article (a, an), definite article (the) and zero article. It's concluded that the article errors which were done by the three students who wrote their skripsi are indefinite articles (a, an), definite article (the) and zero article, the three students write article errors as 34 times of 27 sentences and the three students cannot revise the article errors successfully because lack of knowledge of using articles as well as lack of attention to find out proof readers to make better papers.
\end{abstract}

Kata Kunci: Writing, Research, Students' Skripsi Error, Error In Article.

\section{INTRODUCTION}

Writing paper scientifically is formally done by students in formal education. The students write the paper for expressing their ideas, feelings and thoughts. Writing the paper scientifically is not easy. It needs skills to make a scientific writing. As the students, however, writing activity is obliged to do since it is as a requirement to pass on the lectures in institute/university. To write clearly it is essential to understand the basic system of a language. It includes knowledge of grammar, punctuation and sentence structure. Vocabulary is also necessary, as is spelling and formatting.

One of the most difficult part of English grammar for the EFL/ESL learners is English articles system, said by Master in Dianto (online) while English articles (a, an and the) are considered to be the most frequent words in English. In other words it is said that ESL/EFL learners need more time to acquire the article system than any other grammatical forms. Furthermore Wall Street English in Dianto (online) states that article is one of common error that often encounters toward student in writing English paper.

Since the students often make errors, according to Kaezhavarz (2012:77), "Errors are considered to be systematic, governed by rule, and appear because a learner's knowledge of the rules of the target language is incomplete". Furthermore he continues saying, "Errors are regarded as rule-governed since they follow the rules of the learners' interlanguage".

\section{Errors are different with mistakes.}

According to Kaezhavarz (2012:77), Mistakes are random deviations, unrelated to any system, and instead representing the same types of performance mistakes that might be occurred in the speech or writing of native speakers, such as lips of the tongue or pen, false starts, lack of subject-verb agreement in a long complicated sentence, and the like.

\footnotetext{
${ }^{1}$ Prodi: Pendidikan Bahasa Inggris, Fakultas Bahasa dan Seni, IKIP Gunungsitoli

Email: yannaqueencer@gmail.com
} 
Of both of the theories above, it is said that errors and mistakes are unavoidable done by the students but in different cases. Errors are referred to the rules or systems but mistakes are addressed to unrelated any system. A same thing happens to the students of English education study program of IKIP Gunungsitoli. The students at the eighth semester who are busy arranging their final paper as a requirement to be scholars of education, they often make a lot of errors on their paper, either in research proposal or in their skripsi. One of them is using articles. Thesis advisors focus on guiding them to write the final paper systematically, following the guidance book systematic and all rules of how to write a scientific paper. In fact, the students cannot avoid the errors. A lot of suggestions are addressed to them by thesis advisors and examiners, but it is often done unsuccessfully.

To see how the students use articles, how many times and why cannot be revised successfully, Huebner 1984 in Liu (2015) has developed a system of analysis that accounts for article use in all contexts, that is to say, in all pre-noun positions. The systems describe two things namely the semantic function of each noun phrase used with that NP function and the ways in which this article + NP function changes over time. He continues saying that to determine with that accuracy articles are used; one considers what is used in Standard English that are definite article, indefinite article and zero articles. Therefore, a teacher-researcher was interested in investigating the paper by doing a research entitled 'An Analysis of Students' Skripsi Errors in Using Articles at English Education Study Program of IKIP Gunungsitoli Year 2018/2019'.

In the research, the problem has been formulated by the teacher-researcher that is, what are article errors done by the students? How many times are the students writing article errors? Why cannot the students revise the article errors successfully?. Since the schedule of conducting the research was very limited, so the teacher-researcher focused on 3 skripsi only and particularly Chapter I to be searched only. They were skripsi written by Oinike Laoli, Dian Desrini Harefa and Firman Jaya Waruwu. Three of skripsi were written in academic year 2018/2019 particularly in odd semester since the three students finished their study earlier.

\section{Definition of Error}

According to J. Richard et al., (2002:184-online), "An error is the use of a word, speech act or grammatical items in such a way it seems imperfect and significant of an incomplete learning". Further, Norrish (1983:7-online) says, "Error as a systematic deviation that happens when a learner has not learnt something, and consistently gets it wrong". Hendrickson (197:356online) mentions, "Errors are signals that indicate an actual learning process taking place and that the learner has not yet mastered or shown a well-structured competence in the target language. According to Corder (1976:167-online), Errors are significant of three things, first to the teacher, in that they tell him, if he or she undertakes a systematic analysis, how far towards that goal the learner has progressed and, consequently, what remains for him to learn. Second, they provide the researcher with evidence of how language is learned or acquired, and what strategies or procedures the learner is employing in his discovery of the language. Third, (and in a sense this is their most important aspect) they are indispensable to the learner himself, because we can regard the making of errors as a device the learner uses in order to learn.

Of the definition above, it is stressed that errors are the systematic deviations triggered in the language learning process, or its indications of the actual situation of the language learner themselves which will later help the monitor be it an applied linguist or particularly the language teacher to solve the problem respecting one of the approaches argued in the error analysis.

\section{Errors versus Mistakes}

Chomsky (1965-online) writes, Errors are thought of as indications of an incomplete learning and that the speaker or hearer has not yet accumulated a satisfied language knowledge which can enable them to avoid linguistics misuse. Corder (1967:167-online) mentions, "Mistakes are of no significance to the process of language learning". Of the two different opinions above, it is distinguished that in language there are two things should be explained that are competence and performance. Of the two, error and mistake are possible identified as 
Chomsky says that it is made a fundamental distinction between competence and performance. Competence is the speaker-hearer's knowledge of her/his language and performance is the actual use of language in concrete situations. Relating knowledge with competence and performance, competence is significant enough to represent the speaker's competence to be judged by means of errors that concern the amount of linguistic data while performance is the actual use of language does not represent the language knowledge that the speaker has.

According to J. Richard et al (2002-online) people may have the competence to produce an infinitely long sentence but when they actually attempt to use this knowledge (to perform) there are many reasons why they are restricted in any one sentence. In summary, error and mistake are totally different defined. Error is referred to the competence while mistake is referred the performance.

\section{Grammatical Errors}

Based on Wulandari's finding (2014-online), grammatical errors found in articles are categorized into four. They are omission, misformation, addition and misordering. Errors of omission such as some moslem, Nietzsche ... conscious, other theorist, Islam society ...formed, these reason, all their personal, one of the background, either for, in order ... we, and one of the strategy. Errors of misformation, for example: for persuade, all thing, becomes, the logical coherent, is some reason, because of + a sentence, an long history have come, Indonesian moslem, character reliable, isn't it?, rising, many attentions, and on the other. Errors of addition are the others creatures, can limits, could synthesized, students, as the same as, and student's interested. The last is errors of misordering, for example: not merely state fail, growth national, and with need customer. Above the errors are possible found on the students' skripsi investigated by the teacher-researcher.

\section{Errors Types Classification}

In second language acquisition, error analysis studies the types and causes of language errors. Errors are classified according to modality, linguistics levels, form, type, cause and norm versus system. In modality, it is about level of proficiency in speaking, writing, reading and listening. In linguistic levels, it consists of pronunciation, grammar, vocabulary and style. In form, they are omission, insertion, and substitution. Then, in type, it is systematic errors/errors in competence versus occasional errors/errors in performance. The last is cause, it is about interference and interlanguage.

Dulay et al (1982-online) say that errors take place when the learners change the surface structure in a particularly systematic manner, thus, the error, no matter what form and type it is, represent a damage at the level of the target language production. J. Richard et al. (2002-online) classify errors in two categories. They are inter lingual error and intra lingual error. Both of them refer to respectively to the negative influence of both the speaker's native language, and the target language itself.

Inter lingual error is caused by the interference of the native language L1 (interference, linguistic interference, and cross linguistic influence), whereby the learner tends to use their linguistic knowledge of L1 on some linguistic features in the target language, however, it often leads to making errors. For example: She sees them, produced according to the word order of English while in French literally She them sees. These sentences show the type of errors aroused by the negative effect of the native language interference. Intra lingual error is an error that takes place due to a particular misuse of a particular rule of the target language, it is, in fact, quite the opposite of inter lingual error, it puts the target language into focus, the target language in this perspective is thought of as an error cause.

Furthermore, intra lingual error is classified into six as in the following:

1. Overgeneralizations

Overgeneralizations error occurs when the speaker/writer applies a grammatical rule in cases where it does not apply. According to Richard et al (2002-online) the errors are caused by the extension of target language rules to inappropriate context. It deals with regular and irregular verbs, as well as the application of plural forms. For example: tooth - tooths, than teeth; go - goed, than went. 
2. Simplifications

It happens when the learners produce simpler linguistic forms than those found in the target language. The learners attempt to be linguistically creative and produce their own poetic sentences/utterances. Corder in Mahmoud (2014:276-online) mentions learners do not have the complex system which they can simplify. This is committed through both of omission and addition of some linguistic elements at the level of spelling and grammar. For example of spelling: no - know; weit - weight. Others are we wait the bus all the time (omission). Students are do their researches every semester (addition).

3. Developmental errors

This kind of errors is somehow part of the overgeneralizations, it is the result of normal pattern of development, such as come - comed, break - breaked.

4. Induced errors

Errors are caused by misleading teaching examples, teachers, sometimes, unconditionally, explain a rule without highlighting the exceptions or the intended message they want to convey. Richard et al (2002-online) provides an example that occurs in preposition such as 'at' and a teacher says 'I am looking at the box'. The students may understand that 'at' means 'under' then they will say 'The cat is at the table' instead of 'the cat is under the table'.

5. Errors of avoidance

This error occurs when the learner fail to apply certain target language rules just because they are thought of to be too difficult.

6. Errors of overproduction

Most of the time beginners overproduce, in such away, they frequently repeat a particular structure. They are supposed to have not yet acquired and accumulated a satisfied linguistic knowledge which can enable them to use finite rules of the target language in order to produce infinite structures. Among classifications, the teacher-researcher focused on type and error cause (intra lingual) in the research.

\section{Definition of Article}

Article is a part of grammar. According to Leacock et al in Sholihatun (2017:54) articles are ideal targets for automatic error detection because they are among the most frequent of English learner errors. In English there are three articles namely a, an, and the. Azar (1999:112) says that the article system 'a/an' is used with a singular generic count noun. However, 'the' is used sometimes with a singular generic count noun (not a plural generic count noun, not a generic non-count noun).

Fry et al, Berry, Master in Sholihatun (2017:54) mention that English article (a, an, the) are considered to be the most frequent words in English. Of the theory it is clear that English articles are important to be learned which is emphasized by Kim and Lakshmana in Sholihatun (2017:54) that ESL/EFL learners need more time to acquire the article system than any other grammatical forms.

\section{Use of Article a or an}

Djamal in Dianto says article a or an is used when an unidentified specimen. The form a is used before a word beginning with a consonant, or a vowel with a consonant sound. The form an is used before words beginning with a vowel $(\mathrm{a}, \mathrm{e}, \mathrm{i}, \mathrm{o}, \mathrm{u})$ or words beginning with a mute $\mathrm{h}$ or individual letters spoken with a vowel sound likes an MP and an SOS. Moreover Harmer (2001) in Sholihatun (2017) mentions that indefinite article (a or an) is used refer to a particular person or thing when the listener/reader does not know which one is being described. It is also used to a member of a group in order to refer to the whole groups.

\section{Use of Article the}

Refers to Djamal the is used when the noun which follows names an identified specimen, that is when it is believed that the hearer knows which person, place or thing the noun. Also Harmer (2001) in Sholihatun (2017) states that definite article (the) is used when the 
reader/listener knows which particular thing or person we are talking about or when there can only be one. It is not used when talking people in general using plural or uncountable nouns.

\section{METHOD}

The research was done by using an approach and research design that was qualitative research particularly descriptive content analysis. As Moleong in Dianto (online) says that a qualitative research deals with a kind of research which does not use statistic procedures in analyzing the data. In a qualitative research, the researcher tends to prior in accurate explanation to analyze and present what have been found. The research was conducted at English education study program of IKIP Gunungsitoli at Jl. Yossudaro No. 118 E/S Gunungstioli. As the research data were taken from the three skripsi done by the eighth semester students that have already joined thesis session on January 2019.

As the informant are Oinike Laoli, Dian Desrini Harefa and Firman Jaya Waruwu as well as some of thesis advisors. Moreover, the procedure of Collecting Research Data as follows.

1. The teacher-researcher found out the three skripsi as the research instruments done by the students in the study program library.

2. The three skripsi was read accurately by the teacher-researcher.

3. Errors found in each skripsi were classified into three articles and three parts.

4. Errors were analyzed to be discussed as its findings.

Furthermore, technique of Analyzing the Research Data are Data Collection as the first step, the instrument written above is found out, read and then comprehended before analyzing them. Data Reduction, as the second step was the data reduced based on the obtained information through the students' skripsi and the interview result from some thesis advisors. Data Explained as further, the final data were explained based on the students' errors in using articles in English and it was focused in three parts only. And Data Presented as Lastly a conclusion was written to answer the research formulation to achieve the research purpose. To check legally data and research findings, four important things are done by the teacherresearcher such validity/credibility, transferability/external validity, dependability/reliability and conformability (neutrality)/objectivity.

To conduct the research, some steps were done by the teacher-researcher as follows, Exploring and formulating the research problem, Deciding a research method, Finding out the three skripsi as the research instruments done by the students in the study program library, Reading three skripsi accurately, Identifying the grammatical errors of articles found in the skirpsi written by the students, Classifying the grammatical errors of articles in three parts, Calculating the grammatical errors of articles using percentage, Drawing conclusion, and Reporting the research findings.

\section{RESULTS AND DISCUSSION}

\section{Article Errors Done by the Three Students}

\section{A. Oinike Laoli}

\section{Chapter I: INTRODUCTION}

a. Background of the Problem

First paragraph

a) The purpose is to enable someone to communicate to others orally. (Second sentence)

Third paragraph

a) It means that the speaker ensure that the listener understand and involve in the communication. (First sentence)

b) The listener must give the response or reaction for speaker. (Second sentence)

c) In other words that, speaking gives opportunity to think, discuss, and extend ideas and point of view based on the topic that discuss. (Fifth sentence)

Fourth Paragraph 
a) Based on the syllabus of Kurikulum 2013 at the eighth grade of SMP Negeri 1 Sagae'adu, the core competence ... (First sentence)

b) While the basic competence is ... (Second sentence)

c) The minimum competence criterion which is decided in the school is 70. (Third sentence)

Fifth paragraph

a) Based on the researcher's observation that was done in SMP Negeri 1 Sogae'adu from March until April, .... (First sentence)

Sixth paragraph

a) Therefore, the researcher found the effect of Six Thinking Hats Strategy is strategy that is used by a teacher in teaching speaking to make the students to be active and comprehend the speaking material well. (Fourth sentence)

Seventh paragraph

a) The population of the research was the eighth grade of SMP Negeri 1 Sogae'adu. (Second sentence)

Key Terms Definitions of the Research

First paragraph

a) The key terms definitions given by researcher are: (First sentence)

\section{B. Dian Desrini Harefa}

1. Chapter I: INTRODUCTION

a. Background of the Problem

First paragraph

a) Communication is a process where someone or groups create and use the information to interact each other in certain environment. (First sentence)

Fourth paragraph

a) Based on the syllabus or curriculum 2013 at the seventh grade of SMP Negeri 3 Gunungsitoli Selatan, the core competence .... (First sentence)

b) The minimum competence criterion which is decided in the school is 60. (Third sentence)

Fifth paragraph

a) Based on the observation that was done by the researcher in SMP Negeri 3 Gunungsitoli Selatan from January until February 2018, .... (First sentence)

The Purpose of the Research

a) The purpose of the research is to find out whether there is or not significant effect of Who Am I Strategy on the students' speaking ability at the seventh grade of SMP Negeri 3 Gunungsitoli Selatan in 2018/2019. (First sentence)

The Hypothesis of the Research

First paragraph

a) The hypothesis of the research were formulated as follows. (First sentence)

The Significances of the Research

Second paragraph

a) ....as an input and guideline for them to vary their strategy in teaching speaking. (Second sentence) 


\section{Firman Jaya Waruwu}

1. Chapter I: INTRODUCTION

a. Background of the Problem

First paragraph

a) Speaking is generally thought to be the most important of the four skills. (First sentence)

b) It is the result of teaching-learning process. (Eighth sentence)

c) Therefore, it is important for the students to master the speaking ability in any languages they learned, in order to do a communication and share the information. (Tenth sentence)

d) It means that successful oral communication in the target language with other speakers serve as a display of successful language acquisition. (Twelfth sentence)

Third paragraph

a) The indicators are expected the students must be able to express their idea based on the picture and observation orally. (Fourth sentence)

b) Based on researcher's observation and interview the English teacher and students also in the field on Tuesday 07th February at the seventh grade of SMP Negeri 1 Gido, ... (First sentence)

The Identification of the Problem

a) The identification of the problem in the research, namely: (First sentence)

The Purpose of the Problem

a) The purpose of the research is to know the significant effect of Tell Me What You See Technique on Students' Ability at the Seventh Grade of SMP Negeri 1 Gido in 2018/2018. (First sentence)

The Hypothesis of the Research

a) The hypothesis of the research are as follows. (First sentence)

\section{DISCUSSION}

1. Data Collection

After the three skripsi found out, read and then comprehended, and analyzed by the teacher-researcher and written the findings above, it is continued to do the next step.

2. Data Reduction

The information obtained form the three students' skripsi and the interview result from the three students and some thesis advisors, the important things are written on the paper while some un-useful information was ignored since it was not in line with the theories written on the paper.

3. Data Explained and 4. Data Presented

After some information obtained from believable sources, either the three skripsi or both of the oral interview result, the teacher-research explains the data in the following discussion.

Three answers of the three research questions posed by the teacher-researcher in Chapter I are described in detail below.

\section{a. Discussion of the First Question: What are article errors done by the students?}

The article errors were done by the students are 'a', 'an' and 'the' as they are in the following.

\section{Oinike Laoli}

$>$ It should be 'without the' since in the previous sentence, word of purpose was not written, is included a singular generic count noun it should be changed into ' $a$ ' according to Thomson in Dianto (see p.9-10). 
It should be 'without the' since in the previous sentence, word of speaker was not written and also word of speaker is included a particular person when readers do not know which one is being described so it should be changed into ' $a$ ' according to Thomson in Dianto (see p.9-10). $\square$ It should be 'without the' since word of communication is uncountable or plural nouns has the meaning is general based on ELC Poylu in Dianto (see p.11).

$>$ It should be 'a', not 'the' for word of response since it was written at first time. Then, it should be written 'the' for word of speaker since it has been written previously as a particular person or identified specimen according to Thomson in Dianto (see p.9-10).

$>$ It should be 'without the' since in the previous sentence, word of topic was not written as well as it is changed 'a',

$>$ It should be 'without the' since in the previous sentence, word of syllabus and core competence were not written, is included a singular generic count noun it should be changed into 'a' according to Thomson in Dianto (see p.9-10).

$>$ It should be 'without the' since in the previous sentence, word of basic competence was not written, is included a singular generic count noun it should be changed into ' $a$ ' according to Thomson in Dianto (see p.9-10).

$>$ It should be 'without the' since in the previous sentence, word of minimum competence was not written, is included a singular generic count noun it should be changed into 'a' according to Thomson in Dianto (see p.9-10).

$>$ It should be 'without the' since in the previous sentence, word of researcher was not written, is included a singular generic count noun, an unidentified specimen, a particular person and representing no particular person so it should be changed into ' $a$ ' according to Thomson in Dianto (see p.9-10).

$>$ It should be 'without the' since in the previous sentence, word of effect was not written as well as it is changed 'an' since word of effect is a particular thing when readers do not know which one is being described or unidentified specimen according to Thomson in Dianto (see p.9-10).

$>$ It should be 'without the' since in the previous sentence, word of population was not written, is included a singular generic count noun, an unidentified specimen, a particular person and representing no particular person so it should be changed into ' $a$ ' according to Thomson in Dianto (see p.9-10).

$>$ It should be with 'the' since in the previous sentences, word of researcher was already written frequently or identified specimen, particular persons according to Thomson in Dianto (see p.9-10).

\section{Dian Desrini Harefa}

$>$ It should be 'without the', word of information was not written previously and it is also involved uncountable noun and no need to use the, according to Thomson in Dianto (see p.9-10).

$>$ It should be 'without the' since in the previous sentence, word of syllabus and core competence were not written, is included a singular generic count noun it should be changed into 'a' according to Thomson in Dianto (see p.9-10).

$>$ It should be 'without the' since in the previous sentence, word of minimum competence was not written, is included a singular generic count noun it should be changed into ' $a$ ' according to Thomson in Dianto (see p.9-10).

$>$ It should be 'with an', not 'the' for word of observation, and 'the' for word of researcher should be changed by ' $a$ ' since both of the words were not written previously, both of the words are a singular generic count noun according to Thomson in Dianto (see p.9-10).

$>$ It should be 'without the' for word of purpose since it was not written the word previously, is included a singular generic count noun it should be changed into ' $a$ ' according to Thomson in Dianto (see p.9-10). 
It should be 'without the' for word of hypothesis since it was not written the word previously, word of hypothesis is uncountable or plural nouns has the meaning is general based on ELC Poylu in Dianto (see p.11).

$>$ It should be 'with a' for word of guideline since it is included as a singular generic countable noun and first it was written, and representing no particular things according to Thomson in Dianto (see p.9-10).

\section{Firman Jaya Waruwu}

$>$ It should be 'without the' for phrase of four skills since it was just written as the first sentence in the paragraph, and it's plural nouns based on ELC Poylu in Dianto (see p.11).

$>$ It should be 'without the' for word of result since it was not written previously is included a singular generic count noun it should be changed into ' $a$ ' according to Thomson in Dianto (see p.9-10).

$>$ It should be 'without the' for words of students and information since both of the words were not written previously. Word of students are plural and information is uncountable noun and no need to use 'the' based on ELC Poylu in Dianto (see p.11).

$>$ It should be 'without the' for word of target language since it was not written previously and it's plural nouns based on ELC Poylu in Dianto (see p.11).

$>$ It should be 'without the' for word of indicators since it was not written previously and it's plural nouns based on ELC Poylu in Dianto (see p.11).

$>$ It should be 'with a' for word of researcher's and 'the' for phrase of English teacher should be changed with 'an' since it was written at the first time, representing no particular persons, unidentified specimen, and a particular person readers do not know which one is being described according to Thomson in Dianto (see p.9-10).

$>$ It should be 'without the' for word of identification as the beginning sentence and also it is included as uncountable noun according to Thomson in Dianto (see p.9-10).

$>$ It should be 'change the' into 'a' for word of purpose since word of purpose is is included a singular generic count noun according to Thomson in Dianto (see p.9-10). and 'the' for word of significant should be changed into ' $a$ ' since word of significant was followed by a singular generic count noun according to Thomson in Dianto (see p.9-10).

$>$ It should be 'without the' for word of hypothesis since it was not written previously and word of hypothesis is uncountable or plural nouns has the meaning is general based on ELC Poylu in Dianto (see p.11).

In the following table, it is seen the article errors which were done by the three students in their chapter I.

Table 2 Result of Three Parts of Errors in Article

\begin{tabular}{|c|c|c|c|c|c|c|c|c|c|c|}
\hline \multirow{2}{*}{ No } & \multirow{2}{*}{ Parts } & \multicolumn{3}{|c|}{ Definite } & \multicolumn{3}{c|}{ Indefinite } & \multicolumn{3}{c|}{ Zero Definite } \\
\cline { 3 - 11 } & OL & DH & FW & OL & DH & FW & OL & DH & FW \\
\hline 1. & Omission & 2 & - & - & 1 & 1 & 1 & - & - & - \\
\hline 2. & Wrong Match & 9 & 4 & 3 & - & - & - & 1 & - & - \\
\hline 3. & Special Rules & - & 2 & 6 & - & - & - & - & 2 & 4 \\
\hline
\end{tabular}

Of the discussion, it is clearly seen that above there are kinds of article errors done by the three students in their skripsi in Chapter I namely indefinite article (a, an), definite article (the) and zero article.

Of the findings too, it is calculated that there were 11 sentences using article errors by Oinike, 7 sentences using article errors by Dian and 9 sentences using article errors by Firman. The total sentences written in Chapter I with their article errors were 27 with the total article errors was 34 . For each part of the three kinds of article errors has percentage as follows.

For omission, it was $5 / 34 \times 100 \%=14.71 \%$

For wrong match, it was $17 / 34 \times 100 \%=50 \%$ 
For special rules, it was $14 / 34 \times 100 \%=41.18 \%$

\section{b. Discussion of the Second Question: How many times are the students writing article errors?}

To answer the second question of the research, the teacher-researcher calculated that the students wrote article errors as 34 times of 27 sentences in their chapter I.

\section{c. Discussion of the Third Question: Why cannot the students revise the article errors successfully?}

The students could not revise the article errors successfully because of some reasons as the result of interview that are:

1) Lack of knowledge of using article.

Wulandari's (2014-online) says that grammatical errors found in articles are categorized into four. They are omission, misformation, addition and misordering. Omission and addition happened in their sentences. Some sentences exactly needed articles but they did not write it and some other sentences did not need articles but they wrote it.

Besides, J. Richard et al. (2002-online) have classified errors in two categories. They are inter lingual error and intra lingual error. Both of them refer to respectively to the negative influence of both the speaker's native language, and the target language itself. Of the statement, it is seen that the threes students who wrote skripsi above were influenced by interference and interlanguage as a cause of inter lingual error. Their own language as Indonesian rarely uses article in their daily life. In addition to intra lingual error is classified into six, two of them were errors of avoidance and errors of over productive. In errors of avoidance, the three students failed to apply certain target language rules just because they thought of to be too difficult. Then, in errors of overproduction, most of the time beginners overproduce, in such away, they frequently repeat a particular structure. They are supposed to have not yet acquired and accumulated a satisfied linguistic knowledge which can enable them to use finite rules of the target language in order to produce infinite structures.

1) They supposed (Result of oral interview) the three kinds of articles were as words that could be added or omitted or even ignored since there was a consideration that they did not influence much meaning of written texts delivered on the paper.

2) Lack of attention to find out proof readers to make better papers.

\section{ACKNOWLEDGEMENTS}

Of all, glory and dignity are given to Jesus Christ who has blessed and accompanied the teacher-researcher to conduct the research and finish its report. Further, the teacher-researcher also thanks to the chief of research bureau who still gives an opportunity to continue writing a report after conducting the research, out of the deadline decided. Hopefully, the incident will never happen again, this is first and last time to break out of the schedule decided.

The teacher-researcher is also thankful to her family since the teacher-researcher is still given time to be free sometimes from the household. May God bless us more and more to be successful in conducting next researches in academic field.

\section{CONCLUSION}

In the following, the teacher-researcher writes some conclusion.

a. The article errors which were done by the three students who wrote their skripsi are indefinite articles ( $\mathrm{a}, \mathrm{an})$, definite article (the) and zero article.

b. The three students write article errors as 34 times of 27 sentences.

c. The three students cannot revise the article errors successfully because lack of knowledge of using articles, a suspicion of using articles can be added, omitted or ignored since a wrong consideration they cannot influence much meaning of written texts delivered on the paper as well as lack of attention to find out proof readers to make better papers. 


\section{REFERENCES}

Azar, Betty (1999). Understanding English Grammar. Without City. Without Pulbisher.

Binangun, Cilacap in the Academic Year 2014/2015. ELT Forum: Journal of English Language Teaching. Vol 5 No 1. Articles. State University of Semarang (online) accessed on May, 2nd, 2019.

Chomsky (1965). Language. (online) accessed on May, 2nd, 2019.

Corder, S.P. (1967). The Significance of Learners Errors. International Review of Applied Linguistics. 5:160-170. Accessed on May 2nd, 2019.

Dianto, Rull. Without Year. An Error Analysis on Students' Ability in Using Articles at Third Semester in STAIN Curup. Accessed on www.academia.edu on May, 2nd, 2019.

Dulay et. al. (1982). Second Language Learning. (online) accessed on May, 2nd, 2019.

Hendrickson. (1997). Errors Analysis in Using Articles. (online) accessed on May, 2nd, 2019.

Huebner, T (1979). Order-of acquisition vs. Dynamic Paradigm: a Comparison of Method in Interlanguage Research. TESOL Quarterly, I3:21-28 (online) accessed on May, 2nd, 2019.

Huebner (1984). Second Language Acquisition. (online) accessed on May, 2nd, 2019.

J. Richard et. al. (2002). Research Methodology in Language Teaching. Cambridge University. USA.

Keshavarz. Mohammad Hossein (2012). Constrative Analysis and Error Analysis. New Edition. Rahnama Press.

Liu, Zirui (2015). Error Analysis in Article. Shaanxi Vocational and Technical College. 710010. China. International Symposium on Social Science. ISSS 2015 (online). accessed on May, 2nd, 2019.

Mahmoud (2014). Second Language Acquisition. (online) accessed on May, 2nd, 2019.

Norrish (1983). Errors Analysis in Using Articles. (online) accessed on May, 2nd, 2019.

Penyusun. Tim (2017). Panduan Penulisan Penelitian. IKIP Gunungsitoli.

Sholihatun (2017). An Error Analysis on the Use of English Article in Descriptive Texts Written by the Eighth Grade Students of SMP Nurul Iman Palembang. English Education Study Program. Faculty of Tarbiyah. Islamic State University Raden Patah. Palembang.

Swasti, Sekar Bayu (2016). An Error Analysis on the Use of English Articles in Students' Written Descriptive Texts A Case of Class X MIA 1 of SMA N 1

Without Name. Without Year. Error Analysis (Linguistics). Online. https://en.m.wikipedia.org. accessed on May 2nd, 2019.

Wulandari, I (2014). Grammatical Errors Found in Articles' Abstract of Indonesian Scholarly Journals. JEELS. Volume 1, Number 1, November 2014. State Elementary School of Jagung - Pagu Kediri, Indonesia (online). Accessed on May 2nd, 2019. 